\title{
Non-Standard Vocabulary of Indonesian Language in Students' Reviews Texts of Vocational School Giri Taruna Bogor
}

\author{
Dwi Septiani \\ Universitas Pamulang \\ email: dosen01401@unpam.ac.id
}

\begin{abstract}
One of the things that students lack mastery of, both at the secondary and tertiary levels, is when writing, namely the lack of accuracy in writing standard vocabulary that is in accordance with standard Indonesian spelling. This study aims to describe the writing of non-standard Indonesian vocabulary in a review text by students of SMK Giri Taruna Bogor. The subjects of this study were students of class XI SMK Giri Taruna Bogor FY 2020/2021 totaling 30. The method used in this study was a qualitative descriptive method. Based on the data obtained, there are 30 simple text reviews for class XI students of SMK Giri Taruna Bogor FY 2020/2021. The result of this research is the finding of writing 125 non-standard vocabularies in all of the students' review texts. Only 1 student review text work with data number 04 has 1 standard vocabulary writing error, namely the word analysis which should be written as analysis. On the other hand, the most non-standard vocabulary writing was done by students with data number 15 , namely there were 10 writings of non-standard vocabulary.
\end{abstract}

Keywords: Non-Standard Vocabulary, Indonesian Language, Review Text

\section{Introduction}

One of the things that are less seen when students write an essay is not being careful in choosing diction. Usually, the existing diction is still not appropriate, either because of errors in use or errors in writing. Errors in usage generally come from the imperfect level of ability in Indonesian so that regional aspects still often exist, while errors in using/writing occur due to weaknesses in understanding linguistic rules. Therefore, the researcher suspects that it is necessary to conduct research on the analysis of affixation errors and the selection of non-standard terms in the review texts of vocational high school students. This of course can be a correction, control, and input, especially for teachers who support Indonesian subjects as a result of which anticipation can be made to improve the language quality of students, especially writing skills.

There are several crucial skills that students must learn as they move from one stage to another in their academic field. These skills are taught in schools to explain to students the various ways that can be done to solve concrete life problems whenever they are faced with these problems. Among these is writing, which is undeniably one of the most important skills that every student must perfect. Writing, as a specialized skill, offers students the opportunity to simultaneously capture many other crucial features that can help them succeed in academics, careers, as well as in other relevant aspects of their lives.

Unfortunately, however, many students do not seem to understand the importance of writing in their lives. That is why, in this article, we will examine, together, some of the importance of writing and why it is so important to students. Cahyaningrum, et al. (2018) revealed that writing competence is very crucial to be taught at various levels of education. In the world of education, the ability to write is one of the skills that are prioritized for development and development, in addition to reading and arithmetic. 
Endah, et al. (2012) argue that writing skills can be developed through simple phases, namely observation, questioning, reasoning, and testing. In line with that, Kusmana (2014) states that this also applies when writing reviews. Through the writing assessment phase, individuals also practice improving their writing skills. As explained by Nugraha et al. (2018), writing activities must continue to be trained. This writing ability also increases if it is supported by a rich vocabulary, interest in learning, and conducive learning activities.

Lack of interest in writing causes students to think that writing is very difficult. This is due to the lack of fluency in the language which makes it difficult for students to write. Based on observations and interviews with teachers, regarding common mistakes, it is known that students have difficulty writing spelling, prefixes, and prepositions. The factors that cause Indonesian spelling errors are (1) lack of attention to the use of Pedoman Umum Ejaan Bahasa Indonesia (PUEBI) taught by teachers, (2) the effect of using devices that teach students to write. according to PUEBI, (3) Students are accustomed to writing abbreviations, for example when using a smartphone. Meanwhile, teachers other than Indonesian did not blame students for writing abbreviations. Speech errors in the field of phonology are speech errors that arise because the human vocal apparatus pronounces the wrong language sounds and there are differences in understanding the definitions of spoken and written language (Ghufron, 2015).

According to Setyawati (2010), errors are in the phonological aspect, including changes, omissions and additions of phonemes. The most common mistakes found in writing standard vocabulary in students' writings. Mastery of standard vocabulary also plays a role in determining the quality of the descriptive text made. Vocabulary (lexicon) is a component of language that contains all information about the meaning and use of words. Thus, all basic words, affixes, repeated words, and compound words in Indonesian can be referred to as Indonesian vocabulary. Vocabulary is also the words that are mastered by a person or group of people in the same environment. This means that the vocabulary mastered by someone in one environment is different from other environments.

The standard word is a form of language use that becomes a model that can be imitated by every use of language who wants to speak correctly (Moeliono, 1989). Furthermore, Moeliono (1989) also explained that the standard standard is a variety of language that has the power of social sanctions and is accepted by the language community as a reference or model. Thus, the standard Indonesian vocabulary is the vocabulary used both in writing and spoken by most people (common and acceptable) in situations of official language use (Septiani, 2017). In addition, the standard Indonesian vocabulary can also be a reference for good and correct Indonesian language norms for Indonesian speakers.

One of the writing skills taught in class XI SMK is writing reviews. The ability to write short story review texts is one of the competencies that students must have in learning Indonesian language and literature (Karnengsih, 2016). Review writing material is one of the material for class XI SMK in the 2013 Revised 2017 Curriculum for even semesters, to be precise in four Basic Competencies (KD): KD 3.16 Comparing the contents of various reviews to find a systematic review ; KD 4.16 Compile a review by paying attention to the results of the comparison of several review texts; 3.17 Analyzing the language of reviews (reviews) of at least two different works; 4.17 Constructing a review of a collection of short stories or novels that have been read. From the learning activities in class XI SMK, students are asked to "Construct a review from a collection of short stories or novels that have been read". This is in accordance with the model of language learning in Indonesia, especially the current Indonesian language, namely text-based learning so that teachers or teachers must try to make students able to present texts independently (Kastiyawan, 2017).

Review text is a text that reviews a work of art that has been witnessed/read previously written in an article that is in accordance with the structure of the text (Kemendikbud, 2013). The review text has the social function of the text, namely, assessing the attractiveness of a work and evaluating the work, both advantages and disadvantages. The review text has a relationship with the reviewer, as stated (Kosasih, 2018). Similar to this opinion, Fardengki et al. (2012) stated that a review is the result of an assessment or 
weighing of the strengths and weaknesses of a book. Thus, it can be interpreted that a review is an essay that discusses, assesses and evaluates a written work about the good or bad quality of the essay.

Review texts receive high attention because factual review texts are textual content resulting from indepth analysis of a problem, including various matters such as considerations, in order to present a fair, objective, and rational assessment of a problem. and textual content checked. Kastiyawan, et al. (2007) also noted that the review text is a text that contains criticism, assessment, or assessment of works that have intellectual copyrights. Review texts require objectivity in assessing literary works so that they are not subjective, for example based on likes or dislikes in relation to the author's personality (Yulidar br. Pohan, 2014).

When reading and evaluating a written work, the author will disclose aspects of the advantages and disadvantages of all written works and objectively the advantages of the book being evaluated and presented to the public. Judging a book or literary work means providing information to the reader as a whole to reject or accept the existence of the book. The author still needs to try to give the reader the impression that their assessment is correct and objective. In developing a review, the author must study and know the appropriate evaluation steps to obtain an objective review score, and the reader can obtain correct information on the strengths and weaknesses of the work.

Review text is related to the description of the quality of a work. However, the lack of teacher guidance and preparation puts pressure on many students in the process. The potential of writing a book review can provide a clear picture to the reader about a book or literary work being reviewed and can motivate reviewers to be involved in reading the book or literary work.

Based on an interview with one of the SMK teachers, it is known that the majority of students in class XI SMK are still having problems with mastering standard vocabulary in writing. One of them is a student review text in class XI SMK Giri Taruna Bogor FY 2020/2021. Thus, the purpose of this study is to describe the writing of non-standard Indonesian vocabulary in the review text of the students of SMK Giri Taruna Bogor.

\section{Methods}

This study used descriptive qualitative method. This descriptive method uses qualitative research in its use. Qualitative research is research that uses a naturalistic approach to seek and find meaning or understanding and phenomena in a special contextual setting. In addition, there are those who say that qualitative research is research that seeks to find contextual meaning as a whole (holistic) based on facts (actions, speech, attitudes, and so on). Research subjects do in a natural setting on a regular basis, according to what was constructed by research subjects to build theories (nometics), look for laws of general applicability, (Halim, 2011).

Primary data is data obtained from the research of a researcher directly from the object. Primary data in research is very important to use. The primary data source used by the author in this study is a simple review text for class XI students of SMK Giri Taruna Bogor FY 2020/2021. After the researcher and several fellow members of Community Service (PKM) held training in writing review texts, the students were asked to write a review text from a novel or short story anthology they had read before. The minimum number of paragraphs that must be written is four paragraphs according to the structure of the review text, namely orientation, interpretation, evaluation, summary. Secondary data is data obtained by a researcher indirectly from the object. This secondary data was obtained from various information media, both from books, internet, journals, and from other data sources that support these studies.

The data collection technique used in this research is documentation. Documentation is used to strengthen the data obtained from observations and interviews. The document is the result of the work of students of class XI SMK Giri Taruna Bogor FY 2020/2021, totaling 30 people. Data analysis techniques in this study include classification, coding, tabulation, correction or correction, interpretation, and inference. 


\section{Results and Discussion}

In this study, it was found that the writing of non-standard vocabulary in the review text of the students of SMK Giri Taruna Bogor. Most errors occur because there are still many students who do not understand the proper use of standard words, standard words that should be written in accordance with those listed in the Big Indonesian Dictionary. In this description section, the author will describe the errors in the use of non-standard words in student review texts. Once the error is identified, the data is analyzed and the results are presented in the bar chart below.

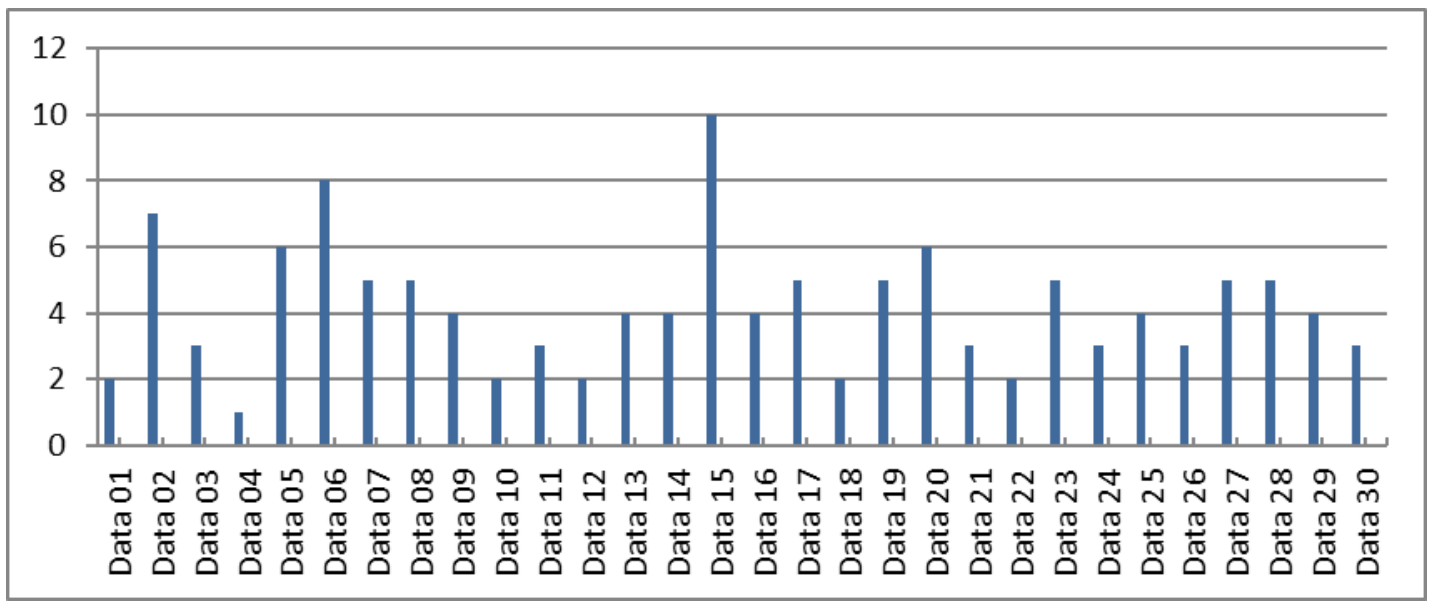

Figure 1. Non-Standard Vocabulary Data

Based on the data above, 30 simple review texts were obtained for class XI students at SMK Giri Taruna Bogor for the 2020/2021 academic year. The total errors in writing standard vocabulary are 125 non-standard vocabularies. Writing non-standard Indonesian vocabulary is found in all of the students' review texts. Only 1 student review text work with data number 04 has only 1 standard vocabulary writing error, namely the word analisa which should be written as analisis. On the other hand, the most common non-standard vocabulary writing was done by students with data number 15 , that is, there were 10 writings of non-standard vocabulary. The following is the data for writing standard vocabulary.

Research results should summarize findings rather than merely presenting detailed research data. Do not describe the numbers (tables/graphs) in detail but rather present the findings or trends. Write down the data that has been processed only in the article (in the form of tables or graphs/images but may not be both for the same data). Statistical data and differences can be presented. It should be written objectively and factually and without expressing personal opinions. Do not discuss it first in the RESULTS section. Only present data that supports discussion only. Do not hide data; it could be that novelty comes from data that is omitted. Do not use the location when referring to pictures or tables, for example: "... presented in Figure 1 below," but "... is presented in Figure 1," or "... (Figure 1)." Consistency: All images/tables presented must be referenced in the body of the text, or vice versa referenced in the body of the text must have images/tables. The table caption is above the table. Figure caption is below the image.

Table 1. Data 15

\begin{tabular}{lll}
\hline No & Nonstandard Words & \multicolumn{1}{c}{ Repair } \\
\hline 1. & dikampung & di kampung \\
2. & kepasar & ke pasar \\
3. & kearah & ke arah \\
4. & menujukan & menujukkan
\end{tabular}


DOI: https://doi.org/10.24036/icolp.v1i1.18

\begin{tabular}{lll} 
5. & kekampung & ke kampung \\
6. & digunung munara & di gunung munara \\
7. & kepuncak & ke puncak \\
8. & disetiap & di setiap \\
9. & diantaranya & di antaranya \\
10. & kesana & ke sana \\
\hline
\end{tabular}

Based on the results of the data recapitulation above, it can be seen that errors in the use of nonstandard words in review texts by class XI students of SMK Giri Taruna Bogor FY 2020/2021 still often occur. The dominant non-standard vocabulary written by students is writing errors of prepositions such as di and ke. The factors behind the occurrence of errors in writing standard vocabulary in the student's writing are ignorance of how to write the right prepositional phrases and the confusion between writing affixed words and prepositional phrases so that the writing of prepositions in and prepositions (prefixes) becomes ambiguous. This is certainly a concern for Indonesian language teachers or teachers to pay more attention to and guide students in various linguistic skills, such as reading and writing so that there is an increase in the quality of students' writing in terms of writing or using standard vocabulary.

This is in accordance with Yetti's (2018) statement that the standard of reading competence, it turns out that the teaching material has presented linguistic studies (spelling, vocabulary, and sentence structure) and writing skills. In addition, language teachers can also provide a variety of quality teaching materials to increase student interest in learning. The selection of appropriate teaching materials in learning greatly affects the quality of student learning success (Sholeh \& Meirani, 2017). Thus, in addition to getting used to writing, a teacher also needs to use strategies, models, or methods that are able to attract students' enthusiasm for learning in learning to write (Rosdiana \& Kamaludin. 2019).

\section{Conclusion}

The most errors occur because there are still many students who do not understand the proper writing of standard vocabulary. Standard vocabulary should be written in accordance with the vocabulary contained in Kamus Besar Bahasa Indonesia (KBBI) or Pedoman Umum Ejaan Bahasa Indonesia (PUEBI). Thus, it is necessary for teachers to allocate appropriate or more time in teaching for students so that they no longer make mistakes in writing standard vocabulary in review texts. Teachers can also provide writing exercises to students and often have discussions in writing standard words. With this research, Indonesian language teachers should pay more attention to students and often communicate, especially regarding the use of standard vocabulary in each student's writing.

\section{Acknowledgments}

The researcher would like to thank the Dean of the Faculty of Letters at the University of Pamulang, the Head of the Indonesian Literature Study Program at the University of Pamulang, the Chairperson of the LPPM at the University of Pamulang, the Head of SMK Giri Taruna Bogor and the teachers, as well as fellow lecturers who have assisted in conducting research and writing this article.

\section{References}

Cahyaningrum, Fitria, Andayani, Saddhono, K. (2018). Peningkatan keterampilan menulis argumentasi melalui model Think Pair Share dan media audiovisual pada siswa kelas X-10 SMA Negeri Kebakkramat. Jurnal Pendidikan dan Kebudayaan, 3(1). 45.

Endah, Nur, Sumarwati, Saddhono, K. (2012). Analisis kesalahan berbahasa Indonesia Siswa Sekolah Menengah Atas. Penelitian Bahasa, Sastra Indonesia dan Pengajarannya, 1(1), 40-53. 
Fardengki, Emidar, Noveria, E. (2012). Korelasi kemampuan membaca pemahaman dan kemampuan menulis resensi siswa kelas IX SMP Negeri 3 Linggo Sari Bagati. Jurnal Pendidikan Bahasa dan Sastra Indonesia, 1(1), 639-645.

Ghufron, S. (2015). Kesalahan berbahasa Indonesia: Teori dan aplikasi”. Yogyakarta: Penerbit Ombak.

Halim, A. H. (2011). Metode penelitian bahasa. Bandung: Remaja Rosdakarya.

Karnengsih, E. (2016). Penerapan metode Discovery Learning melalui teknik "Barendistup" dalam pembelajaran menulis teks ulasan cerpen. Bahasa dan Sastra Indonesia, 3(2), 153-164.

Kastiyawan, M. A., Hudiyono, Y. Ahmad, M. R. (2017). Pengembangan media Levidio Storyboard dalam pembelajaran menulis teks ulasan film/drama pada siswa kelas XI SMK. Journals of Culture, Arts, Literature, and Linguistics, 3(1), 21-22.

Kemendikbud. (2013). Peraturan Menteri Pendidikan Dan Kebudayaan Nomor 65. Kemendikbud

Kosasih, E. (2018). Jenis-jenis teks. Bandung: Yrama Widya.

Nugraha ,V., Permana, I., dan Permana, A. (2018). Pembelajaran menulis resensi novel Pertemuan Dua Hati Dan Laskar Pelangi menggunakan teknik comparing. Jurnal Ilmiah UPT P2M STKIP Siliwangi, 5(2), 55-61.

Pohan, E. Y. (2014). Pengaruh model pembelajaran Collaborative Learning terhadap kemampuan menulis resensi cerpen oleh siswa kelas XI SMA persiapan stabat tahun pembelajaran 2013/2014. Jurnal Basastra, 3(4), 6-7.

Rosdiana, I., Subarna, I., \& Kamaludin, T. (2019). Keefektivan penggunaan metode Think Talk Write dalam pembelajaran menulis teks ulasan pada siswa MTS. Parole (Jurnal Pendidikan Bahasa dan Sastra Indonesia), 2(4), 571-578.

Setyawati, N. (2010). Analisis kesalahan berbahasa Indonesia: Teori dan praktik. Surakarta: Yuma Pustaka.

Septiani, D. (2017). Influence of larning interest and vocabulary on the writing description of secondary school in Depok. Hortatori: Jurnal Pendidikan Bahasa dan Sastra Indonesia, 1(2), 169-178.

Sholeh, K., \& Meirani, D. A. (2017). Nilai pendidikan akhlak film Rumah Tanpa Jendela Karya Aditya Gumay dan penerapannya dalam pembelajaran interpretasi makna teks ulasan drama/film di kelas XI SMA/SMK. In Prosiding Seminar Nasional \& Internasional (Vol. 1, No. 1).

Yetti, R. (2018). Implementasi model Window Shopping dalam pembelajaran membandingkan teks ulasan film pada siswa kelas XI TKR SMK Negeri 5 Pekanbaru Semester 2 Tahun Pelajaran 2017-2018. Journal on Education, 1(1), 75-82. 